\title{
Adrenergic beta-receptor sensitivity in essential tremor
}

\author{
HEIKKI TERÄVÄINEN, T ANDREO LARSEN \\ From the Department of Neurology, University of Helsinki, Helsinki, Finland
}

SUMMARY Adrenergic beta-receptor sensitivity of six male patients with essential tremor and six age-matched normal controls was assessed by measuring the response in the heart rate and postural tremor to incremental injections of the adrenergic beta-agonist isoprenaline. The relative increase in heart rate and tremor in essential tremor patients did not differ from that in normal controls. It is concluded that no major abnormality is likely to exist in the peripheral adrenergic beta-receptor sensitivity in essential tremor.

The pathophysiology of essential tremor is not known. A functional difference in adrenergic neurotransmission could exist in this disease since adrenergic beta-receptor antagonists reduce tremor amplitude in the majority of patients. An attempt was therefore made to analyse beta-receptor sensitivity in patients with essential tremor known to respond favourably to propranolol.

\section{Material and methods}

Six male patients with essential tremor were studied. They were $20-48$ years of age (mean 40 ). The results were compared with observations on six normal volunteers 26-59 (mean 39.5 ) years of age. Four of the patients had a family history of tremor and three had noticed that alcohol suppressed the tremor. All responded to oral non-selective beta-adrenoceptor agonist medication. All the subjects studied had given informed consent to their participation after explanation of the procedures and potential risks involved.

Peripheral adrenergic beta-receptor sensitivity was estimated by administering varying concentrations of isoprenaline hydrochloride intravenously using the method described by Cleaveland $e t$ al. ${ }^{1}$ Different concentrations of the drug were injected rapidly into the left cubital vein of supine subjects. Injections were started with a low dose $(0.25 \mu \mathrm{g})$, which was then doubled until an increase of about 30 beats per minute (bpm) in the heart rate was obtained. Saline-placebo injections were given intermit-

Address for reprint requests: $\mathrm{Dr} \mathrm{H}$ Teräväenn, Department of Neurology, University Central Hospital, Haartmaninkatu 4, SF00290 Helsinki 29, Finland

Received 19 December 1983 and in revised form 3 May 1984. Accepted 5 May 1984 tently. Throughout the test the ECG was monitored using standard recording techniques. In addition, a computer was used to measure the $R R$ intervals for 30 seconds before and 1.5 minutes after the isoprenaline injection, to calculate the relative increase in the heart rate and to give a graphic display of the RR intervals converted to the bpm value throughout the follow-up period (fig 1). Chronotrophic dose $\left(C D_{25}\right)$, defined as the dose of isoprenaline $\mathrm{HCl}$ in $\mu \mathrm{g}$ needed to increase the heart rate by 25 beats per minute, was calculated from these figures. ${ }^{1}$ The $\mathrm{CD}_{25}$ was considered to give one estimate of the adrenergic betareceptor sensitivity of subjects studied, though mostly of the beta- 1 receptors. A parameter presumed to reflect adrenergic beta-2-receptor sensitivity, at least to some extent, was based on evaluation of the tremor enhancement, caused by isoprenaline injections, which is known to occur in both normal subjects ${ }^{23}$ and essential tremor patients. ${ }^{2} 45$ Postural tremor of the subjects' right hand was recorded with a Grass SPA accelerometer attached to the middle finger while the subjects held their hand elevated horizontally. The tremor signal was amplified, full-wave rectified, and integrated in $10 \mathrm{~s}$ periods to obtain a cumulative value of tremor. The subjects were asked to raise their arm repeatedly for a period of 30 to $40 \mathrm{~s}$, followed by a rest period of about $30 \mathrm{~s}$. The average of the two to three $10 \mathrm{~s}$ periods thus obtained was used as a value for the tremor intensity at a given time. An example of such an experiment is shown in fig 2 . At least two recordings were obtained before the injections. The recordings were continued as described for four to five minutes after the injections. During this period the enhanced tremor had already decreased to a variable degree, the peak values being obtained between 1.5 and 3.5 minutes after the injections. Thereafter, the tremor recordings were individually controlled until the amplitude had reached the pre-injection level. This occurred within 15 minutes, the time being longer with higher isoproterenol dosages. Student's $t$ test was used in statistical evaluations. 


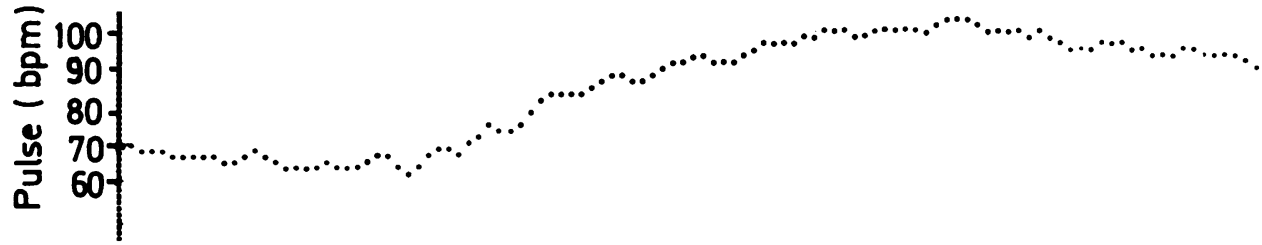

Fig 1 Computer print-out of tachycardia in a patient with essential tremor given an injection of $4 \mu \mathrm{g}$ isoprenaline $\mathrm{HCl}$ iv at the beginning of the display. Heart rate began to increase about $20 \mathrm{~s}$ after the injection. Small fluctuations in the response represents beat-to-beat variation of the heart rate induced by respiration (respiratory sinus arrhythmia). The duration of the print-out is about one minute.

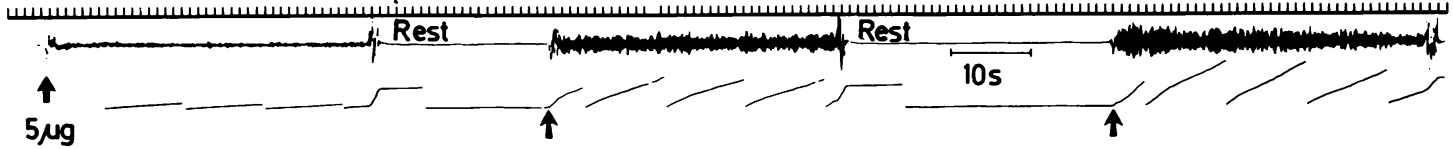

Fig 2 Continuous recording of postural tremor in a patient who was given $5 \mu$ isoprenaline HCl at the time illustrated. At that point the subject raised his hand horizontally for about $40 \mathrm{~s}$, followed by a rest of some $20 \mathrm{~s}$. Two additional periods of tremor recordings are illustrated by arrows. The patient's tremor is shown below the time scale. The lower scale shows the cumulative tremor intensity over 10 s periods throughout the recording.

\section{Results}

Isoprenaline injections caused a dose-dependent increase in both the heart rate and tremor amplitude in both the normal subjects and essential tremor patients. The increase in the heart rate began about $25 \mathrm{~s}$ after the injection and reached a maximum about $20 \mathrm{~s}$ later (fig 1). Tremor intensity increased between 1 and 1.5 minutes, reaching maximum values between 1.5 and 3 minutes after isoprenaline injections. Figure 2 illustrates an actual recording from a patient with essential tremor given $5 \mu \mathrm{g}$ of

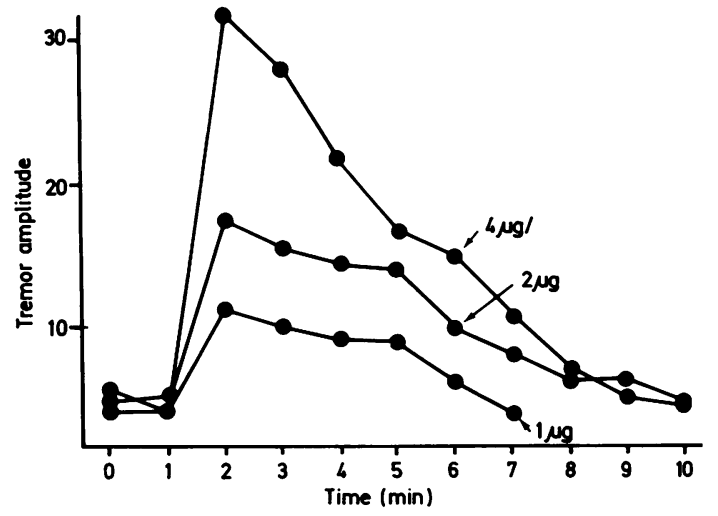

Fig 3 The figure is a summary of recordings of tremor intensity at a one minute invervals over a period of 10 minutes each in a patient given three different dosages of isoprenaline $\mathrm{HCl}$ intravenously. Increase in tremor amplitude occurred after one minute, that is later than the increase in the heart rate (fig 1). isoprenaline hydrochloride iv. The effects of different isoprenaline dosages on tremor and the duration of tremor enhancement are illustrated in fig 3 .

The $\mathrm{CD}_{25}$ value obtained for the essential tremor patients $(4.1 \pm 1.5 \mu \mathrm{g})$ did not differ from that calculation for the normal controls $(4.4 \pm 1.2 \mu \mathrm{g})$. Respective resting pulse rates were $77.0 \pm 8.4$ and $70.3 \pm 6.4 \mathrm{bpm}$. On the other hand, the maximum intensities of the tremor after the isoprenaline injections were higher in the essential tremor patients (table) but so were the preinjection levels. The relative increase in the tremor was somewhat more pronounced in the patients $(107 \%)$ than in the normal controls $(91 \%)$, but the difference was not statistically significant.

\section{Discussion}

Essential tremor amplitude is greatly exacerbated by stress, excitement or fear, sympathomimetics and various stimulants such as coffee and tobacco. Apart from the known hereditary disposition the pathophysiological mechanisms of essential tremor are obscure. Marshall ${ }^{6}$ proposed that essential tremor is an exaggerated form of physiological tremor involving oscillations within the peripheral reflex arch. Contributions by the central nervous system are indicated by the fact that stereotaxic operations on the brain relieve tremor ${ }^{7-9}$ and that it disappears from the hemiplegic side following a stroke. ${ }^{810}$ Oscillation in the olivorubrocerebellar loop has been proposed to be of importance. "12 Patients benefit to a limited extent only from minor tranquilisers, ${ }^{13}$ apparently more from primidone ${ }^{14-16}$ and especially from ethyl alcohol. ${ }^{17}$ 
Table Effect of $i v$ isoprenaline $\mathrm{HCl}$ on postural tremor (mean $\pm S D$ ) in essential tremor patients and normal subjects

\begin{tabular}{lcccc}
\hline & Unstimulated tremor & Isoprenaline tremor & Isoprenaline dose ( $\mu g)$ & $\begin{array}{l}\text { \% increase of tremor per } \\
\text { I } \mu g \text { isoprenaline }\end{array}$ \\
\hline Patients & $7 \cdot 1 \pm 2 \cdot 4$ & $32 \cdot 3 \pm 8 \cdot 7$ & $4 \cdot 5 \pm 0.5$ & $107 \pm 25$ \\
Normal subjects & $2 \cdot 2 \pm 0.4$ & $9 \cdot 0 \pm 2 \cdot 9$ & $4 \cdot 5 \pm 0.8$ & $91 \pm 11$ \\
\hline
\end{tabular}

Adrenergic beta-blocking drugs have been the treatment of choice for more than ten years, the non-specific blockers being more effective than the cardioselective ones. ${ }^{17}$ The observation that alphaadrenergic blocking drugs also suppress essential tremor $^{18}$ awaits confirmation. The therapeutic effect of the adrenergic beta-blocking drugs in essential tremor ${ }^{171920}$ could theoretically be based on functional differences in the receptor sensitivity of essential tremor patients compared to normal subjects. The present results indicate that there are no major differences between patients and normal volunteers in the cardiovascular beta-receptor sensitivity measured as chronotropic response to intravenous isoprenaline hydrochloride. Further more, the relative increases in the postural tremor of the patients and the normal volunteers were of roughly the same magnitude. These results are interpreted to indicate that adrenergic beta-receptor sensitivity is within normal limits in patients with essential tremor. This interpretation is limited to the cardiovascular system and to the part of the motor system accessible to intravenous isoprenaline. The present study cannot exclude the possibility that differences exist in the adrenergic beta-receptor sensitivity in the central nervous system since isoprenaline hydrochloride is not believed to cross the blood-brain barrier. Another theoretical possibility is that isoprenaline may not penetrate the capsule surrounding muscle spindles which may or may not contain adrenergic beta-receptors.

\section{References}

${ }^{1}$ Cleaveland CR, Rangno RE, Shand DG. A standardized isoproterenol sensitivity test. The effects of sinus arrhythmia, atropine, and propranolol. Arch Intern Med 1972;130:47-52.

${ }^{2}$ Young RR, Growdon JH, Shahani BT. Beta-adrenergic mechanisms in action tremor. $N$ Engl $J$ Med 1975;293:950-3.

${ }^{3}$ Marsden CD, Foley TH, Owen AL, McAllister RG. Peripheral beta-adrenergic receptors concerned with tremor. Clin Sci 1967;33:53-65.

${ }^{4}$ McAllister RG Markesberry WR, Ware RW, Howell
SM. Suppression of essential tremor by propranolol: correlation of effect with drug plasma levels and intensity of beta-adrenergic blockade. Ann Neurol 1977;1:160-6.

${ }^{5}$ Teräväinen H. Beta-blockers in isoproterenol-enhanced essential tremor. Acta Neurol Scand 1984;69:125-7.

- Marshall J. Observations on essential tremor. J Neurol Neurosurg Psychiatry 1962;25:122-5.

${ }^{7}$ Cooper IS. Heredofamiliar tremor abolition by chemothalamectomy. Arch Neurol 1962;7:129-31.

${ }^{8}$ Laitinen L. Stereotaxic treatment of hereditary tremor. Acta Neurol Scand 1965;41:74-9.

${ }^{9}$ Bertrand C. Stereotaxic and peripheral surgery for the control of movement disorders. In: Barbeau A, ed. Disorders of Movement. Lancaster: MTP Press 1981:191-208.

${ }^{10}$ Mylle G, VanBogaert L. Etudes anatomo-cliniques de sydromes hypercinetiques complexes. I. sur le tremblement familiar. Mschr Psychiatr Neurol 1940; 103:28-43.

"Lee RG, Stein RB. Resetting of tremor by mechanical perturbations: a comparison of essential tremor and parkinsonian tremor. Ann Neurol 1981;10:523-31.

${ }^{12}$ Bathien N, Rondot P, Toma S. Inhibition and synchronisation of tremor induced by muscle twitch. J Neurol Neurosurg Psychiatry 1980;43:713-8.

${ }^{13}$ Magee KR. Essential tremor: diagnosis and treatment. Clin Med 1965;72:33-41.

${ }^{14}$ Chakrabarti A, Pearse JMS. Essential tremor: response to primidone. J Neurol Neurosurg Psychiatry 1981;44:650.

is O'Brien MD, Upton AR, Toseland PA. Benign familiar tremor treated with primidone. $\mathrm{Br}$ Med J 1981;282: 178-80.

${ }^{16}$ Findley LJ, Calzetti S. Double-blind controlled study of primidone in essential tremor: preliminary results. $\mathrm{Br}$ Med J 1982;282:608.

${ }^{17}$ Larsen TA, Calne DB. Essential tremor. Clin Neuropharmacol 1983;6:185-206.

${ }^{18}$ Mai J, Olsen RB. Depression of essential tremor by alpha-adrenergic blockade. J Neurol Neurosurg Psychiatry 1981;44:1171.

${ }^{19}$ Sevitt I. The effect of adrenergic beta-receptor blocking drugs on tremor. Practitioner 1971;207:677-8.

${ }^{20}$ Winkler GF, Young RR. The control of essential tremor by propranolol. Trans Am Neurol Assoc 1971;96:66-8. 